\title{
The Effect Of Immersion Time Variation in Polyvynyl Piprolidone Against Characteristics Of Scaffold Biocomposit Of Bacterial-Hydrocysiatatic Cellulose as Candidate
}

\author{
Ludita Woro Indrio ${ }^{1 *}$, Djoni Izak Rudyardjo² dan Jan Ady \\ ${ }^{1}$ Study Program S1-Technobiomedic, Faculty of Science and Technology, Universitas \\ Airlangga \\ ${ }^{2}$ Department Physics, Fakultas Faculty of Science and Technology, Universitas Airlangga \\ ${ }^{3}$ Department Clinical Pharmacy, Faculty of Pharmacy, Universitas Airlangga \\ *Corresponding author: luditaworo@gmail.com
}

\begin{abstract}
Bone defects due to trauma, tumors, congenital abnormalities, degeneration and other diseases are still major problems in the field of orthopedics and traumatology. Based on data in Asia, Indonesia is the country with the highest number of fracture sufferers, there are as many as 300-400 cases of bone surgery per month in hospitals. Dr. Soetomo Surabaya (Gunawarman et al, 2010). Repair of damaged bones can be overcome with material that can accelerate the process of bone healing (bone healing). This research was conducted to synthesize hydroxyaparite bacterial cellulose scaffold as a candidate for bone healing. Bacterial cellulose as a matrix was synthesized by culturing Acetobacter xylnum, while hydroxyapatite as filler was synthesized by immersion into a solution of $\mathrm{CaCl} 2$ and $\mathrm{Na} 2 \mathrm{HPO} 4$, the scaffold formation process using freeze dried method. Composite formation was varied by immersion in Polyvynil pirrolidone (PVP) for 0, 1, 2, 3, 4 days. Furthermore, samples were characterized using FTIR-Spectroscopy showing the presence of carbonates containing apatite crystals in all five samples.
\end{abstract}

Keywords: bone healing, scaffold, bacterial cellulose, hydroxyapatite, polyvynil pirrolidone

\section{INTRODUCTION}

Bone defects due to trauma, tumors, congenital abnormalities, degeneration and other diseases are still major problems in the field of orthopedics and traumatology (Ferdiansyah, 2011). The Indonesian Ministry of Health obtained data on fracture cases with different types of fractures and different causes of about eight million people, from the results of the Ministry of Health RI survey found $25 \%$ of patients with fractures died, $45 \%$ experienced physical disabilities, $15 \%$ experienced psychological stress and $10 \%$ experienced good recovery (MOH, 2009). Based on data in Asia, Indonesia is the country with the highest number of fracture sufferers, there are as many as 300-400 cases of bone surgery per month in hospitals. Dr. 
Soetomo Surabaya (Gunawarman et al, 2010).

Bone repair and regeneration is indeed a complex problem in the field of orthopedic surgery, every year millions of people suffer from bone disease, bone trauma and bone tumors (Murugan, 2004). Bone repair that is damaged can be overcome with material that can accelerate the process of bone healing (bone healing). The choice of biomaterials that will be implanted in the application of bone healing (bone healing) must have properties such as human bones, among others, easy to obtain, biocompatible, bioactive and not toxic (Riyani, 2005).

Currently a variety of materials have been developed that are well used for bone reconstruction, one of which is hydroxyapatite. Hydroxyapatite is a mineral compound and part of the group of apatite minerals, with the chemical formula $\mathrm{Ca} 10(\mathrm{PO} 4) 6(\mathrm{OH}) 2$ which has similar chemical composition with bone tissue Bahrololoom et al., 2009). Mineral hydroxyapatite is a good material for bone transplants because it can bind to bone and is biocompatible and osteoinductive (Windarti and Astuti, 2006). But hydroxyapatite has properties that are not easily degraded (Indrani, 2012), for this reason a material that is able to overcome these problems is needed. The material that is most likely to meet these criteria is composite. This composite material must be stable when in contact with body fluids and other aqueous solutions. The material is bacterial cellulose (Windarti and Astuti, 2006).
Bacterial cellulose is a primary metabolite product produced by cellulose-producing bacteria from species Aerobacter, Azetobacter, Alcaligenes, and Acetobacter. The bacterium Acetobacter xylinum, also known as the Gluconacetobacter xylinus bacterium, is the type of bacteria that is most widely used as a model in studies of cellulose (Shoda et al., 2005). Bacterial cellulose products from Acetobacter xylinum are biocompatible polymers with good physical and chemical properties seen from the characteristics of using high tensile strength (16 Mpa), elastic modulus and hydrophilicity (Helenius et al., 2006). Important characteristics of Bacterial cellulose in addition to biocompatible is bioinert, biodegradable and selective permeability. In addition, bacterial cellulose can fight microorganisms so that it accelerates the process of bone healing (bone healing). Bacterial cellulose shows good elasticity, high wet strength (conformity) and conformability (Saska et al., 2011). The morphology of the structure of bacterial cellulose fibers is similar to that of collagen fibers from human bones (Tazi et al., 2012).

In a previous study conducted by Yin et al (2011) biocomposite of bacterial cellulose hydroxyapatite with biomimetic method was made which was immersion in Polyvynil pirrolidone (PVP) for two days and then immersed in $\mathrm{CaCl} 2$ solution for three days and Simulated Body Fluid (SBF) for 5 and 7 days. In PVP immersion for 2 days, a Ca / $\mathrm{P}$ ratio of around 1.5 was produced. While theoretically, 
hydroxyapatite has calcium content (in weight) of 39.68; phosphorus 18.45 with a $\mathrm{Ca} / \mathrm{P}$ ratio of 1.67 (Kawai et al., 2004). While the study of Saska et al (2011) conducted a study with the same material as biocomposite bacterial cellulose - hydroxyapatite for the $\mathrm{Ca} / \mathrm{P}$ ratio still not reached 1.67 but in this study the method used was more effective by doing soaking in $\mathrm{CaCl} 2$ and Na2HPO4 for 12 hours in the formation of apatite crystals. So that in this study modifications were made by forming submerged apatite crystals in a solution of $\mathrm{CaCl} 2$ and $\mathrm{Na} 2 \mathrm{HPO} 4$ with variations in the immersion time of Polyvynil pirrolidone (PVP) for $0,1,2,3,4$ days, soaking in the PVP network to expand the fiber network many bind $\mathrm{Ca} 2+$ and PO43-. ionPolyvynil pirrolidone (PVP) becomes a solvent and is a biocompatible polymer that has been shown to be effective in promoting the formation of apatite crystals (Yin et al., 2011).

In this study using biocomposite bacterial cellulose-hydroxyapatite, where bacterial cellulose is used as a composite matrix because it has a high surface activity consisting of fibril fibers (Yamane et al., 2004) and hydroxyapatite as its filling material. Variation of soaking Polyvynil pirrolidone (PVP) carried out

\section{METHODS}

\section{Characteristics of Chemical Bonds with FTIR-}

\section{Spectroscopy}

This test was conducted to determine the chemical bonds in the sample using the Fourier Transform Infa Red Spectroscopy (FTIR- for $0,1,2,3,4$ days is expected to increase the $\mathrm{Ca}$ / $\mathrm{P}$ ratio.

Bone healing candidate is in the form of scaffold with the freeze dried method which is effective in supporting pore formation (Al Shamary and Al Darwash, 2013). Scaffolds should have interconnection scale pores that are suitable to support integration and vascular tissue, chemical reactions that help cell surfaces, differentiation and proliferation, adequate mechanical properties and must be made from biodegradable or bioresorbable material so that tissue will replace scaffold (Hutmacher, 2001).

Biocomposite scaffold formed by hydroxyapatite bacterial cellulose is characterized by several tests, namely tests to determine chemical bonds using the Fourier Transform Infrared Spectroscopy (FTIRSpectroscopy) tool, test to determine the surface morphology of the material, surface topographic structure, and identify the elements by phase using the Energy Dispersive X-Ray (EDAX) Scanning Electron Microscopy (EDAX), the material degradation ability test is a degradation test in Simulated Body Fluid (SBF), and the test knows the percentage of shaft formed by conducting porosity tests.

Spectroscopy) tool. Samples were characterized by infrared spectroscopy from laser light reflected by prisms. To do the FTIR test, $\mathrm{KBr}$ powder is needed as a background placed on stainless steel, the selection of $\mathrm{KBr}$ because the cells in the sample footage must be made of 
infrared translucent material, one of which is $\mathrm{KBr}$. Then -hydroxyapatite bacterial cellulose samples which have been freeze dried are ground together until smooth to eliminate the scattering effect of large crystals. The powder mixture is then formed pellets by pressing mechanically so that the infrared ray spectrum can be passed.

\section{RESULTS AND DISCUSSION}

\section{FTIR Test Results - Spectroscopy}

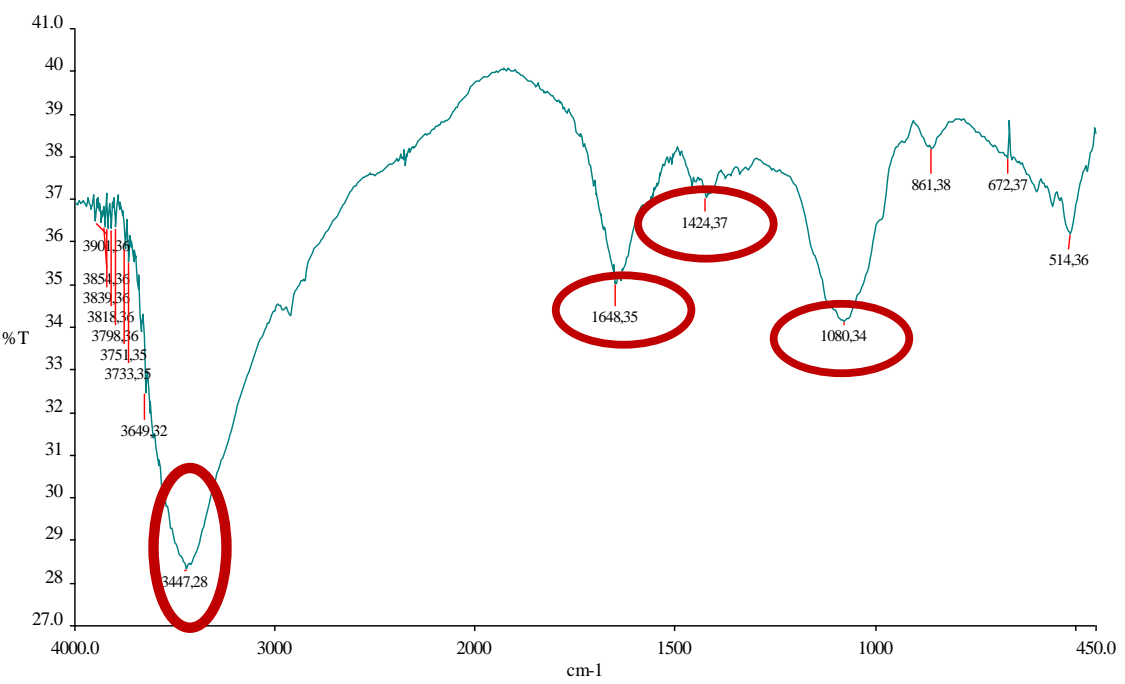

Figure 1. Spectra of FTIR Cellulose Bacteria - Hydroxyapatite Scaffold (Control)

Figure 1 is an FTIR spectra of freeze dried bacterial-hydroxyapatite cellulose which shows the presence of several identical compounds according to the chemical formula of hydroxyapatite namely Ca10 (PO4) $6(\mathrm{OH}) 2$. At wave number $3404 \mathrm{~cm}^{-1}, 3447 \mathrm{~cm}^{-1} 1$ and 3649 $\mathrm{cm}^{-1}$ are $\mathrm{OH}$ groups (stretching), at wave number $2928 \mathrm{~cm}^{-1}$ is $\mathrm{CH}$ group (stretching), at wave number $1055 \mathrm{~cm}^{-1}$ and $1080 \mathrm{~cm}^{-1}$ is a $\mathrm{C}-\mathrm{O}$ (stretching) group, at wave number $1648 \mathrm{~cm}^{-1}$ is a group $\mathrm{C}=\mathrm{O}$, at wave number $1424 \mathrm{~cm}^{-1}$ is a CO32-group, and the number of waves $1080 \mathrm{~cm}$ 1 is a PO43- group (Saska et al, 2011).

The bacterial-hydroxyapatite cellulose spectrum (control) was compared with variations in PVP immersion for 1, 2, 3, 4 days, there was stretching vibration at peak wave number $3447 \mathrm{~cm}^{-1}$ (control) on variation of 1 day PVP immersion to $3464 \mathrm{~cm}^{-1}$, in variations 2-day PVP immersion became $3467 \mathrm{~cm}^{-1}$, in the 3-day immersion variation to $3466 \mathrm{~cm}^{-1}$, and in the 4-day immersion variation to $3468 \mathrm{~cm}^{-1} 1$ (Figure 2; 3; 4; 5). This shows the interaction of hydroxyl groups with $\mathrm{C}=\mathrm{O}$ in $\mathrm{PVP}$. The presence of $\mathrm{C}=\mathrm{O}$ in $\mathrm{PVP}$ provides additional electron bonds to absorb more $\mathrm{Ca}^{+}$(Yin et al, 2011). At the frequency of the shift in the wave number, it is expected that the $-\mathrm{OH}$ bond found in bacterial cellulose can bind to the $-\mathrm{O}$ bond present in PVP.

Table 2. Wave Numbers of Cellulose Bacterial Scaffold - Hydroxyapatite with PVP Immersion Variations 


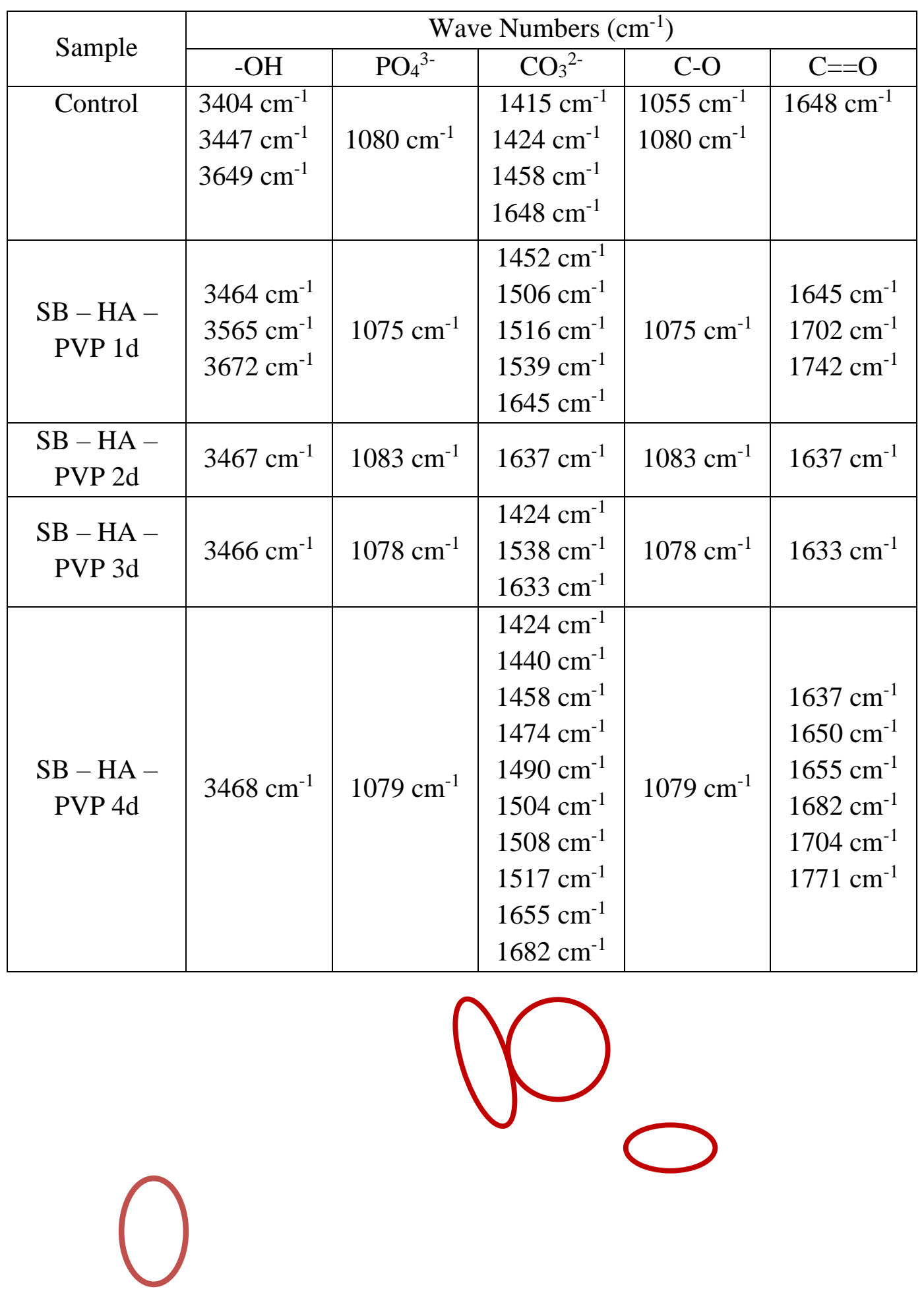

Figure 2. Spectra of FTIR Cellulose Bacteria Scaffold - Hydroxyapatite with PVP immersion for 1 day

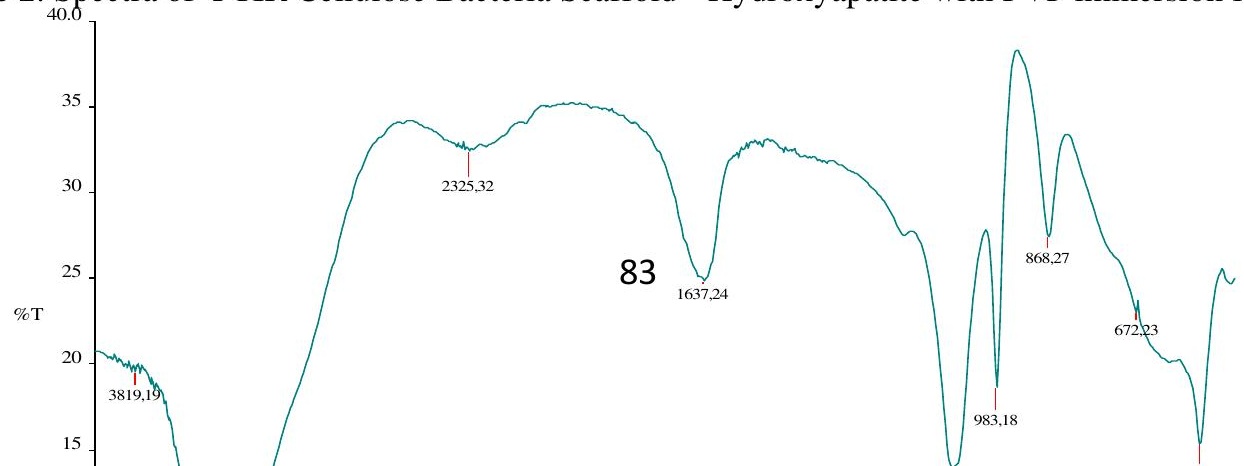



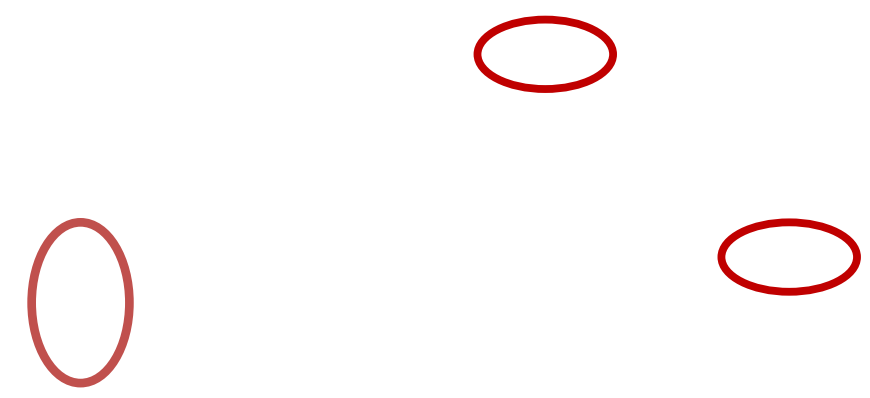

Figure 3. FTIR Spectra of Cellulose Bacteria Scaffold - Hydroxyapatite with PVP immersion for 2 days

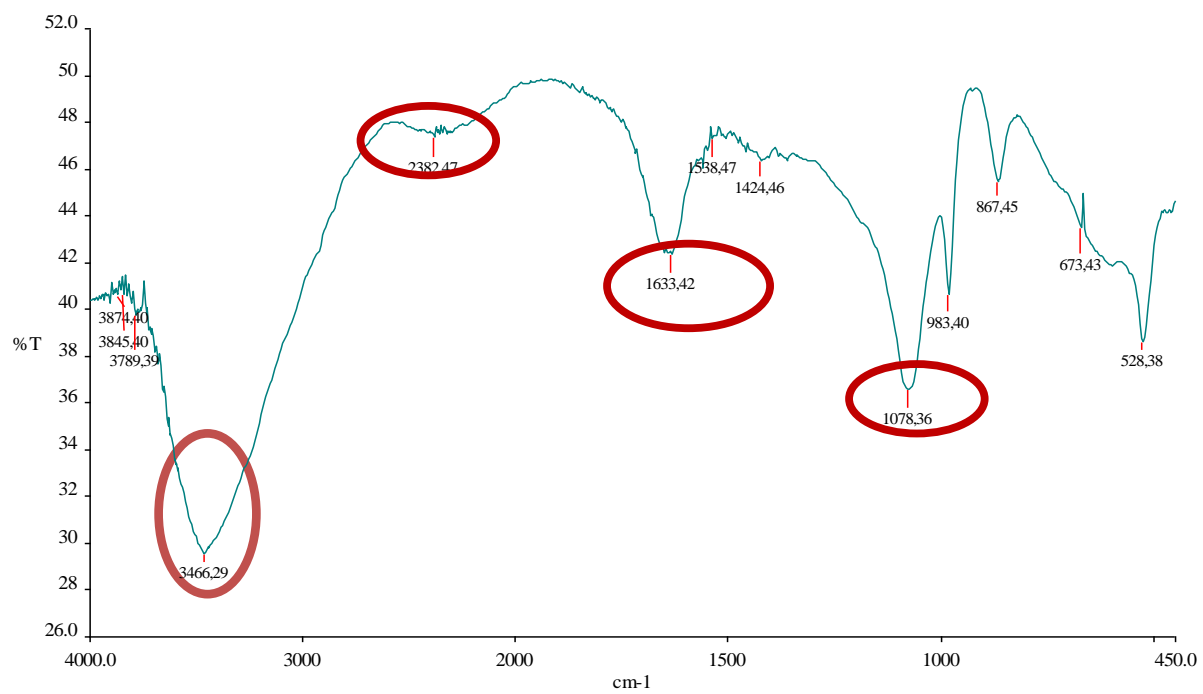

Figure 4. Spectra of FTIR Cellulose Bacteria Scaffold - Hydroxyapatite with PVP immersion for 3 days

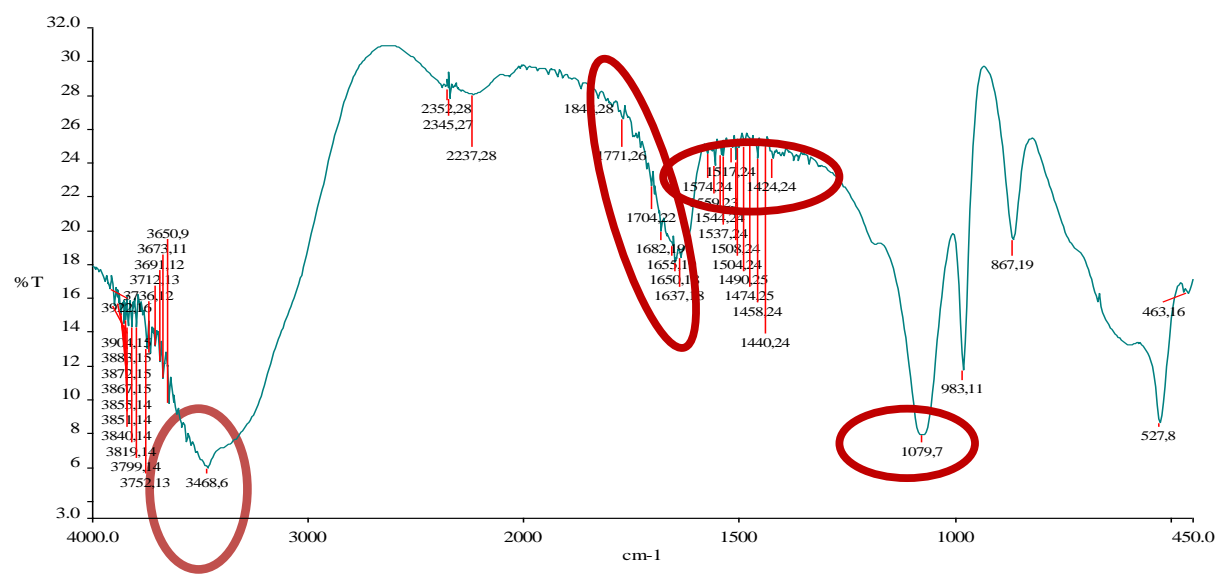

Figure 5. FTIR Spectra of Cellulose Bacteria Scaffold - Hydroxyapatite with PVP immersion for 4 days

\section{CONCLUSION}

Effect of variations in immersion time in Polyvynil pirrolidone (PVP) in the synthesis of bacterial cellulose - hydroxyapatite scaffold. Chemical bond analysis with FTIR-Spectroscopy 
of the five samples showed the presence of carbonates containing apatite crystals.

\section{REFERENCES}

Al-Shamary, Elhan Esmaeel dan Al-Darwash, Amir Khalaf. 2013. Infleuncene of Fermentation Condition and Alkali Treatment on The porosity and Thickness Bacterial Cellulose Membranes. The Online Journal of Science and Technology, Volume 3, Issue 2.

Bahrololoom ME., et al. 2009. Characteristic of Natural Hydroxyapatite Extracted from Bovin Cortical Bone Ash. Journal of Ceramic Processing Research 10(2): 129-138.

Departemen Kesehatan Republik Indonesia. 1979. Farmakope Indonesia Edisi III. Departemen Kesehatan Republik Indonesia: Jakarta.

Flottmann, Hubertus, dan Quadir, Anisul. 2008. Polyvynil pyrrolidone (PVP) - One of The Most Widely Used Exipients in The Pharmaceuticals: An Overview. Drug Delivery Technology.

Gunawarman, Malik, A., Mulyadi S., Riana, Hayati, A. 2010. Karakteristik Fisik dan Mekanik Tulang Sapi Variasi Berat Hidup sebagai Referensi Desain Material Implan. Seminar Nasional Tahunan Teknik Mesin (SNMTTM) ke9.
Helenius, G., et al. 2006. In Vivo Biocompatibility of Bacterial Cellulose. J Biomed Mater Res A 76: 431- 438.

Hutchens, SA., et al. Composite Material. United States Patent 20040096509.

Indrani, Decky J. 2012. Komposit Hidroksiapatit Kalsinasi Suhu Rendah dengan Alginat Sargassum Duplicatum atau Sargassum Crassifolium sebagai Material Scaffold untuk Pertumbuhan Sel Punca

Mesenkimal. Universitas Indonesia: Jakarta.

Jiang, Liuyun., Li, Yubao., Wang, Xuejiang., Zhang Li., Wen Jiqie., Gong, Mei. 2008. Preparation and Properties of Nanohydroxyapatite/Chitosan/Carboxymetyl Cellulose Composite Scaffold. Research Center for Nano-Biomaterials, Analytical and Testing Center, Sichuan University: China.

Kawai, T., et al. 2004. Coating on an Apatite Layer on Polyamide Films Containing Sulfonic Groups by a Biomimetic Process. Biomaterials, 25, 4529-4534.

Keaveny, Tony M. 2004. Bone Mechanics. Universitas of California, San Frasisco, California and Unversitas of California, Berkeley, California.

Kokubo, T dan Takadama, H. 2006. How Useful is SBF in Predicting In Vivo Bone 
Bioactivity, $b$ Biomaterials. 27 (15), 2907-2915.

Saska, S., et al. 2011. Bacterial CelluloseHydroxyapatite Nanocompocytes for Bone Regeneration. International Journal of Biomaterials. Volume 2011. University Estadual Paulista: Brazil.

Sulistiono, GS. dkk. 2012. Sintesis Hidroksipatit Berpori dengan Porogen Kitosan dan Karakteristiknya. PAIR BATAN: Jakarta.

Shoda, M., et al. 2005. Recent Advamces in Bacterial Cellulose Production. Biotechnology and Bioprocess Engineering, 10, 1-8.

Tazi, Neftaha., et al. 2012. Hidroxyapatite Bioactivated Bacterial Cellulose Promotes Osteoblast Growth and The Formation of Bone Nodules. AMB Express, a Springer Open Journal.

Torres, Fernando G., et al. 2012. Biocompatibility of Bacterial Celullose
Based Biomaterials. Journal of Functional Biomaterials.

Warastuti, Yessy dan Suryani, Nani. 2013. Karakteristik Degradasi dari Biomaterial Poli (kaprolakton-kitosanhidroksiapatit) Iradiasi dalam Larutan Simulated Body Fluid. Pusat Aplikasi Teknologi Isotop dan Radiasi, BATAN: Jakarta Selatan.

Windarti, Tri dan Astuti, Yayuk. 2006. Pengaruh Konsentrasi $\mathrm{Ca}^{2+}$ dan $\mathrm{PO}_{4}{ }^{3}$ pada Pembentukan Hidroksiapatit dalam Matriks Selulosa Bakteri. Universitas Diponegoro: Semarang.

Yamane, C., et al. 2004. Novel Cellulose-Type Material. United States Patent 20040267006, Desember 30, 2004.

Yin, Na., Chen, Shi-yan., Ouyang, Yang., Tang, Liang., Yang, Jing-xuan., Wang, Huaping.. 2011. Biomimetic Mineraliation Synthetis of Hydroxyapatite Bacterial Cellulose Nanocomposite. Donghua University:Shanghai. 